DOI: $10.15838 / \mathrm{esc} / 2015.2 .38 .5$

UDC 331.538, LBC 65.24

(C) Toreev V.B.

\title{
Employment strategy of the Russians
}

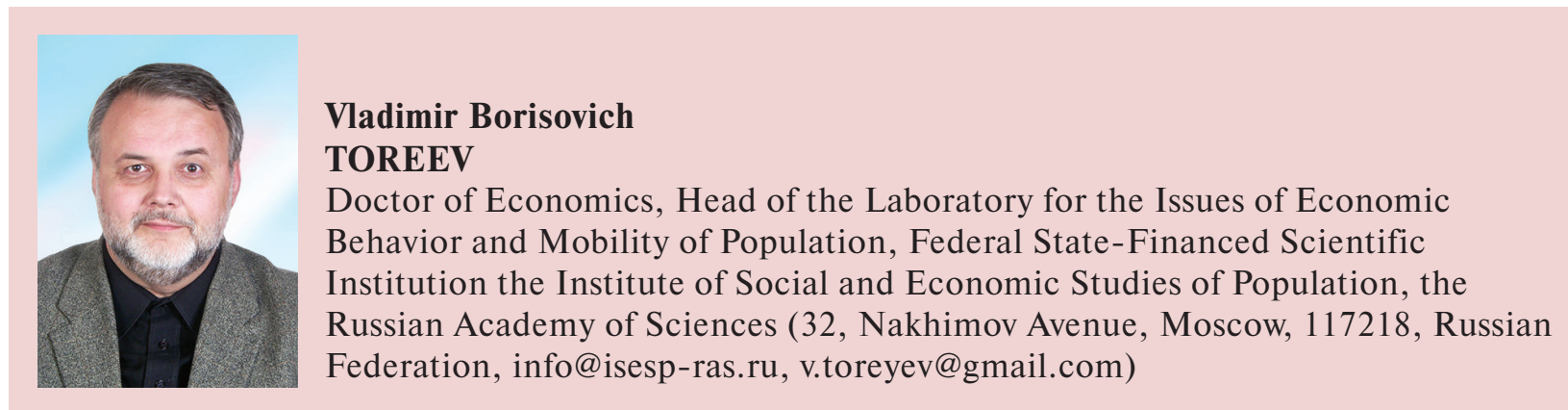

Abstract. During the crisis it is especially important to choose a correct employment strategy. Every employee uses an employment strategy, as he/she selects the direction of long-term employment consciously or intuitively. The choice of strategy is determined by a number of factors shaping the person's attitudes: health, character, upbringing, education, social environment, institutional environment. The employment strategies of the young people newly entering the labor market differ from lab our strategies of workers. Young people do not have such experience and can plan their life "from scratch". The Soviet specialists, people who started their career in the planned economy, have their own features of employment strategies. The article describes employment strategies of the Russians.

Key words: employment strategy, the youth, workers, Soviet specialists, health, education, institutional environment.

This article presents the results of the research focused on the complete classification of labor strategies of the Russians. Most research on this topic was conducted at the turn of the century and during the last ten years the scientific community has lost interest in this topic. Hence, there are no relevant scientific works. Meanwhile, Russia is constantly experiencing institutional and socio-economic changes: the education reform, several economic crises, development of the system small enterprises support, etc. They limit the range of employment strategies. The scientific novelty of this study is as follows: first, employees are divided into 2 groups: those who first enters the labor market (young people) and constantly working; 
employment strategies of Soviet specialists, characterized by some specific features, are singled out in a separate group; second, the attempt was made to create a complete list of fundamental employment strategies.

We understand the employment strategy as a conscious choice of the direction of long term employment made by an employee. There are factors determining the ability of people to choose some optimal employment strategy.

1. Health. The presence of diseases limits the choice of employment strategies. Disability has a severe impact on the choice of work. It is especially difficult to determine the employment strategy for lifelong disabled people. To get a job, they have to show their will and determination.

2. Innate character features. The character features, such as persistence in achieving goals, diligence and ability to perceive information, promote career planning, i.e. reasonable choice of employment strategies. People with this character understand what they want to achieve in life since childhood and strive to achieve it.

3. Upbringing. Upbringing can compensate a lack of inherent character features. Parents bring up children, but sometimes the life circumstances have a strong impact on the character formation. Overcoming life difficulties, people form their character.

4. Education. The level of education is one of the key parameters that determine the choice of an employment strategy. Secondary education limits the possibility to obtain an interesting, well-paid job; postsecondary education gives an opportunity to continue education at university or apply acquired knowledge in production and make a working career. Finally, higher education provides an interesting, well-paid job and career prospects.

5. Social environment. Social environment influences the formation of people's world perception. It forms the general level of culture and value orientations of a person, thus, affecting the choice of an employment strategy. Quite often children choose work occupations of their parents, as they are familiar with them from childhood. There are well-known families of military officers, artists, doctors, musicians; a young man who has grown up in the family, which has small business, can set up new or continue family business easier, etc.

6. Institutional environment. It defines a set of alternatives that are available to a person, imposing severe restrictions on the choice. The labor market, where the employment strategy is implemented, determines the demand for some professions, which do not always coincide with person's desires.

As a result, the choice of an employment strategy is influenced by many factors, which form some rational attitudes of a person. Attitudes can be either material, such as maximization of income, or idealistic, such as the choice of interesting work. If the choice were only rational, for example, in order to maximize revenue, 
then we would have no musicians, actors, scientists and other low-paid workers.

In practice, both approaches are combined and the labor strategy is chosen depending on the predominance of one or another attitude of an individual. Thus, the choice of an employment strategy is the comparison of acquired attitudes with the possibilities of their realization.

We will distinguish employment strategies of young people, i.e. people born after the 1992 economic reforms and the relevant socio-political transformation and newly entering the labor market ${ }^{1}$, and adult persons, i.e. people who have joined the labor market long ago.

\section{Employment strategy of the youth}

The young people differ from other actors of the labor market, as they can choose any employment strategy. They do not feel the burden of past mistakes. Their common feature is susceptibility to influence of the external environment, i.e. television, radio, social media, electronic games, etc. Their parents got the first work by assignment; today's young people do not have state guarantees of employment. They have to enter the labor market after we presentgraduation and promote themselves.

We present young people's definitions of good work (tab. 1).

Table 1. Distribution of young people answers to the question:

"What requirements should the work meet to satisfy you?"*

\begin{tabular}{|c|l|c|c|}
\hline No. & \multicolumn{1}{|c|}{ Answers of respondents } & Number of answers & $\%$ \\
\hline 1. & Well-paid & 1525 & 84.9 \\
\hline 2. & Interesting for me & 1141 & 63.5 \\
\hline 3. & With good work conditions & 521 & 29.0 \\
\hline 4. & Providing opportunities for professional growth & 466 & 25.9 \\
\hline 5. & Diverse, creative, initiative involving & 293 & 16.3 \\
\hline 6. & Useful to society & 255 & 14.2 \\
\hline 7. & Prestigious & 236 & 13.1 \\
\hline 8. & Leaving plenty of time for other activities (recreation, family, study) & 235 & 13.1 \\
\hline 9. & Providing an opportunity to make a career quickly & 228 & 12.7 \\
\hline 10. & Not tiring & 111 & 6.2 \\
\hline & TOTAL & 1769 & 100.0 \\
\hline * VTSIOM sociological research "Youth of the new Russia: lifestyle and value priorities" was carried out in 2007, 1769 young people were \\
surveyed in 12 regions of Russia, cities of Moscow and Saint Petersburg.
\end{tabular}

1 Let us consider young people aged $17-29$ as the youth, as is done in most studies. In other cases we will specify the age.

2 The respondents could choose multiple answers, so the number of responses exceeds the number of respondents. 
For the absolute majority of young people the work should be well-paid ( $84.9 \%$ of the respondents ${ }^{2}$ ). The attitude that that without material prosperity it is impossible to make own life has become the dominant factor promoted by the external environment. Interesting work $(63.5 \%)$ is the next most frequent answer.

Consequently, the image of future work looks like an "interesting job". Let us note that all the employees in Russia would like to have such work. Other responses are less frequent. So, for $29 \%$ of the respondents their work should be comfortable (with good conditions) and for $25.9 \%$ - it should ensure professional growth. Interestingly, not so many young people demonstrate hedonistic mood: for $13.1 \%$ of the respondents the work should leave much time for other activities and for $6.2 \%$ - it should not be tiring.
The answers to the question: "What do you think, what helps get a good job primarily?" give an idea about the way to have good work (tab. 2).

The most popular answer reveals that young people understand the high importance of education. This corresponds to the number of young people seeking to enter higher education establishments after school. However, more than half of the respondents believe that the path to a good job is laid through contacts and acquaintances. Therefore, young people can build their employment strategy without good education or enter prestigious institutions in order to obtain the "degree", as they rely on contacts and acquaintances to get a good job. The number of the respondents, considering hard work and study as a way to success, only slightly exceeds the number of the respondents,

Table 2. Distribution of young people' answers to the question:

"What do you think, what helps get a good job primarily?"

\begin{tabular}{|c|l|c|c|}
\hline No. & \multicolumn{1}{|c|}{ Answers of respondents } & Number of answers & $\%$ \\
\hline 1. & High qualification, knowledge & 1143 & 63.6 \\
\hline 2. & Contacts and acquaintances & 945 & 52.6 \\
\hline 3. & Readiness to work hard & 561 & 31.2 \\
\hline 4. & Specialty that is now highly valued & 555 & 30.9 \\
\hline 5. & Initiativity, entrepreneurial attitude & 513 & 28.6 \\
\hline 6. & Discipline, diligence, responsibility & 491 & 27.3 \\
\hline 7. & Ability to get along with authorities & 367 & 20.4 \\
\hline 8. & Other & 15 & 0.8 \\
\hline & TOTAL & 1769 & 100.0 \\
\hline
\end{tabular}


relying on good connections. People, willing to work hard, are those who seek for receiving a highly-valued degree.

Based on the preferences in the choice of grounds for getting a good job, we can define the basic employment strategy youth.

Deliberate professionalism. According to this employment strategy, young people choose future profession quite early and consistently pursue their ambition: get proper education and acquire necessary competences and skills. Professions, chosen by young people, require good eight year educations: six years for basic education and a master's degree and two years for second higher education.

Usually the positions, occupied by people with such training, provide them with a good salary and career growth. However, sometimes it is enough to have only basic education and, for example, know foreign languages in order to use this strategy successfully. There is quite a large group of young people who use this strategy without getting higher education. There are popular work occupations, which do not require higher education: mechanics, operators, seamstresses, etc. They provide an acceptable level of wages and satisfy the need for self-realization. To get such jobs, it is enough to go to a college.

Professionalism. Unlike the previous strategy, young people are not sure about future profession. Without any purpose, they go to a college, for example, "for the company", or following the advice of parents, or as it is close to home. They believe that good education will help them become successful on the labor market and they are ready to work hard to get it. They can change their work occupation and, accordingly, the university, when they understand what profession they want to receive.

The first two labor strategies are implemented by young people who consider high skills and knowledge as a way to get a good job. Sometimes they receive second higher education in foreign universities, thus becoming more competitive to be employed in foreign companies operating in Russia. Usually they behave actively on the labor market, searching for a job that would satisfy their ambitions.

According to the results of the departmental monitoring carried out by the Ministry of Education and Science of the Russian Federation, in December 2012 best employed were graduates of engineering departments, such as "Aviation and Space-Rocket Engineering", "Marine Engineering", "Energy, Power Engineering and Electrical Engineering" and "Metallurgy, Engineering and MetalWorking Manufacturing". The share of the graduates, unemployed in this field, does not exceed $5 \%$. The possibilities to get a job after getting a degree in Economics are completely different. As for the field "Humanities", only $53 \%$ of the graduates could get a job place, "Education and Pedagogy" - 48\%, "Social Sciences" $45 \%$ [1]. 
Protectionism. This employment strategy is used by young people who rely on contacts and acquaintances. Sometimes to get protection it is important to get a particular degree, that is why they go to a certain university or college; sometimes only a degree is required. Some private institutions do not provide quality education, but they see to it that a graduate has a degree. This youth category is provided with a job place in advance. They find it difficult to change it, even if they do not like it, as they are not psychologically ready to search for new jobs.

Stable career. This is the strategy, pursued by the young graduates, preferring a stable career with gradual implementa-tion of life plans. In most cases they work in public organizations, consistently passing the way from the lowest to managerial positions. Usually the budget enterprises provide their employees with a variety of additional social services (health, recreation, child care, etc.) that can serve as a bonus to small salaries.

Own business. In accordance with this strategy, young people are eager to create their own business. This often occurs when their relatives or the inner circle do business, and young people begin to learn business under their supervision. The studies show that education, better higher, is required to manage a small enterprise [2]. Secondary education is enough for individual entrepreneurship. Some young people start their business studying at the university, for example, providing services for installation, checkout and maintenance of computers. More often young people under 25 become heads of small enterprises under the supervision of experienced people. This helps avoid fatal mistakes that lead to bankruptcy.

Survival. This employment strategy is characteristic of young people who are forced to start their career early for some reason, for example, feed themselves or their dependent relatives. Without education, they have to get the worstpaid jobs. Quite often the orphanages' leavers use this strategy. Unfortunately, to change this employment strategy is almost impossible, at least until the circumstances change.

Players. These group members perceive life as continuation of a certain computer game. They change jobs easily, sometimes due to quarrelsome characters, sometimes wanting to try as much as possible in this life. They focus on social networks, where they live, and the real life is somewhere outside of their attention. They live in anticipation of a big win and believe that they will be lucky in the end.

Apathy. This employment strategy is selected by the youth who chooses not to work. Having the opportunity to receive money from relatives and friends, they try not to work. And if they are employed, they do everything to have them fired. The infantile attitude to work is caused by a number of factors: improper upbringing; 
desire for a beautiful life, formed in adolescence under the influence of social networks, television and clan ambitions; deviations in the psyche, etc. Often such young people become alcoholics and drug addicts. Sometimes this period lasts a long time (up to the age of 40 longer), i.e. until the sources of money are run out. Not necessarily the family of such young people should be wealthy; on the contrary, they can pull money from elderly parentspensioners and be unfair to people who love them.

Finally, all young people who do not use the previously described strategy can be attributed to the group of "undecided". This is a group of young people who have no conscious labor strategies. Usually these people do not take pains in studying, and they are called weak learners or middlings, depending on the abilities. They leave schools, colleges or even graduate from universities without understanding where to work. Entering the labor market, they use different search strategies [3], but work out of necessity or are not satisfied with their work. Perhaps, gradually, they can develop their own employment strategy, but early in life they drift along, not knowing where they can come to.

It should be noted that young people working at state-owned enterprises, more often work in their specialty: $70 \%$ of the employed at state-owned enterprises and only half of the employed at private enterprises claim that their work corresponds to the specialty specified in the diploma. A quarter of young people who have got special training never work in their field. The greatest number of employees who do not work in their specialty is observed among young entrepreneurs (53\%), young employees in the service sector (45\%), workers at enterprises, mines, construction sites (43\%). Young people living in big cities work in their specialty more often than those living in medium and small cities or rural settlements. Young people who have started their career while studying at the university or college find jobs in their specialty and adapt to it faster [4].

Most young people, before finding a job place, have a period of unemployment. This also applies to high school graduates not admitted to universities and graduates of universities and colleges. To a lesser extent this applies to graduates who have received engineering degrees. Table 3 presents the results of the monitoring, carried out by the Ministry of Education and Science of the Russian Federation, in relation to the 2011 engineering graduates, seeking assistance in employment agencies.

As the table shows, the largest number of engineering graduates goes to employment agencies in the Siberian Federal district and the Far Eastern Federal district, and the lowest number - in the Central Federal district and the Northwestern Federal district. 
Table 3. Number of the 2011 engineering graduates seeking assistance in employment agencies

\begin{tabular}{|l|c|c|}
\hline \multicolumn{1}{|c|}{ Federal district } & $\begin{array}{c}\text { Number of applicants } \\
\text { to employment agencies, \% }\end{array}$ & $\begin{array}{c}\text { Number of recognized } \\
\text { unemployed, \% }\end{array}$ \\
\hline Central & 2.72 & 1.47 \\
\hline Northwestern & 2.95 & 1.57 \\
\hline Southern & 6.54 & 3.84 \\
\hline North Caucasusian & 6.15 & 4.98 \\
\hline Volga & 3.50 & 1.91 \\
\hline Ural & 4.56 & 2.33 \\
\hline Siberian & 8.37 & 4.74 \\
\hline Far Eastern & 7.03 & 4.23 \\
\hline TOTAL in Russia & 4.37 & 2.47 \\
\hline
\end{tabular}

\section{Employment strategies of employees}

The citizens, who have started their career, also have their employment strategies, which are well described [5, 6, 7]. The labor market has been recently developing rapidly to increase requirements to the level of employees' professionalism.

In terms of the labor force quality, the labor market can be divided into the market of skilled and low-skilled jobs. Skilled jobs, as a rule, can be occupied by the workers with higher and secondary special education. This is administrative staff, engineers, employees with high and medium qualifications. This group has a relatively high level of wages and certain guarantees stable employment. Unskilled jobs require no special training and qualification. They are for workers without education and work experience, i.e. employees in the service sector, laborers at construction sites, etc.

They are characterized by lower wages and job security.
The typology of the occupational structure of labor force supply can be performed in the following groups [8]:

- work occupations of highly skilled, creative and intellectual labor characterized by growing demand;

- mass work occupations of interdisciplinary application characterized by stable demand: demand in these workers is determined by the economical trends;

- unattractive work occupations of heavy, low-skilled manual and unhealthy labor that do not meet socio-cultural and psycho-physical requirements of the modern workforce; they are still characterized by sharp shortage and low quality of the labor potential;

- work occupations, the demand for which falls due to structural and technological restructuring, and free workers need retraining and re-qualification;

- undervalued and underpaid work occupations. 
There are major employment strategies of the Russians.

Career growth. This strategy is more common among work occupations requiring high qualifications. An employee consistently goes through all the stages of professional development. For this strategy, an employee should constantly enhance his/her professional level: read special literature, develop new methods, participate in conferences, undergo training aimed at improving skills. This strategy can be implemented at one enterprise due to the change of a job place.

Salary maximizition. The employees using this strategy pursue material success. They can improve their skills, but can change the place of work and the work occupation easily, if they seem it favorable. There is a variation of this strategy, such as the strategy to maximize income without great effort. People practicing this strategy want to work in accordance with their duties and obtain the highest possible salary, but are not ready to take pains to raise their professional level.

Combining jobs. This employment strategy is a variation of the salary maximizition strategy, as it is aimed at receiving additional revenue. This strategy is mostly used by the employees of creative (liberal) occupations: journalists, artists, actors, etc. This can also include scientists who teach and accountants who can keep accounts of several enterprises.

This strategy is successfully used by the professionals who have the opportunity to work at home, such as designers, architects, programmers, etc. They can and can not have a permanent place of work.

Stability. This employment strategy is preferred by the workers interested in stability. High wages, though desirable, are not necessary; to have a stable job place is essential. They can change a job if they feel that the new job will be more stable. For the sake of stability they can abandon personal and professional interests and even lower their status. This strategy is used by people who have been unemployed for quite a long time. People of pre-retirement age are more inclined to use it, as they find it difficult to compete with the youth on the labor market, despite their great experience.

Labor minimization. A small number of employees use the strategy, which does not coincide with the theory of rational behavior of an "economic man". Such "workers" ready for anything, only to do nothing or the minimum possible work. They do not care about a low salary level. It is rational if the income from additional work (for example, when combining jobs) is much higher than that at the main job. Or if an employee uses this strategy pursuing hedonistic goals, trying to free as much time as possible for hobby. However, sometimes the labor minimization is a consequence of stand in life.

Own business. This strategy is mostly used by the employees who have worked in the specialty for some time and have gained some professional experience. They use the acquired experience when opening 
their own business. The desire for selfactualization and financial situation improvement is the main stimulus of this employment strategy. Let us note that not everybody succeeds. Approximately one third of the newly formed small businesses go bankrupt after the first year of operation. If the company become insolvent, the owners can be employed at some other enterprise and after some time start their own business. Quite often people who have lost their jobs start business and become forced entrepreneurs. There are programs to combat unemployment (for example, financial support to employment agencies) and programs to set up business.

Forced work. People use this employment strategy against their will. They are forced to take any, even low skilled work to feed themselves and their family. This situation occurs in depressed regions with high unemployment or as a result of personal circumstances. Quite often use this strategy is used by orphanage leavers, single mothers, families with the dependent (disabled children, sick parents, etc.), the old-aged unemployed.

Planned unemployment. Having the opportunity to earn money, the unemployed get registered at employment services and receive unemployment benefits. At the same time, without informing the employment service, they have temporary jobs. If the wages at the temporary work are high enough, the unemployment benefit is perceived as a bonus from the state. After the completion of the benefit period, they easily find work and after some time everything is repeated again [9]. This strategy is characterized by the frequent change of jobs.

\section{Employment strategies of the Soviet specialists}

The consideration of labor policies of the Soviet intelligentsia (teachers, doctors, scientists and engineers) is interesting and important because they stepped from one economic system to another: from planned to market economy. People who got higher education in Soviet times and jobs in accordance with the distribution comprised the Soviet middle class.

They started their career in the Soviet Union during the planned economy, when there was artificial shortage of labor, collectivism was much more important than individualism, the beginning of career was characterized by similar income for everybody and high salary was not considered as a core value. First of all, work should be interesting. The degree of social protection was very high; it was almost impossible to dismiss employees for incompetence, they were protected by the Labor code and trade unions.

The 1992 economic reform changed the institutional environment. As a result, the non-payment of wages on time became commonplace, the inflation reduced purchasing power sharply and the proper wages indexing lacked. The Soviet specialists had to adapt to the changes in the institutional environment [10]. However, the large group of professionals did not 
give up the usual strategy even in those conditions ${ }^{3}$. Work satisfaction, attachment to the staff and the existing way of life and rejection of the new rules of social organization are interviewee's motivations not to change habitual employment strategies. These strategies are often associated with overcoming circumstances and environmental resistance.

We can distinguish four situations, when the former (Soviet) employment strategies can be preserved:

1. High professional qualification of a "Soviet specialist". In such a situation (not very widespread) an employee is in demand on the new labor market, his/her knowledge and professional skills are required by the state or non-state sector, the salary is timely indexed, the social status is not only not reduced, but can be increased.

2. Support of the family. Some members of the household, earning enough, give a chance to others not to make significant changes to working practices.

3. Presence of broad social networks. Their importance in the Soviet society is difficult to overestimate [11]. In the new conditions of the dominance of the economic exchange integration social networks are becoming more important.

3 The research results are presented according to the materials of the CSTI and University Magdeburg joint project, conducted in 2000, aimed at investigating changes in the organization of everyday life of 6 mass professions representatives (military officers, doctors, engineers, scientists, teachers, government officials). 90 interview was taken, 15 for each group. The interviewees were under 40, had higher education, continued working in the specialty received in Soviet times and lived in Saint Petersburg.
"Soviet specialists", having extensive networks, use their "connections" to find a prestigious job, obtain loans, free medical care and additional earnings. Networks help to cope with a variety of problem situations. They are used most successfully where there formal institutions are ineffective. The presence of the significant network resource, when, for example, leaving the armed forces, can help not only find work immediately, but also choose the most acceptable among several offers.

4. Stubborn conservatism. People, adhering to this strategy, do not want to sacrifice the customary way of life for the successful adaptation to new institutional conditions. They can not accept the new rules and literally survive by self-restraint, as they are not ready to change the volume and nature of work.

Not all "Soviet experts" were ready to involuntary restraint. Many people had to flexibly add (develop) their employment strategies. The desire to adapt to new institutional rules led to increased employment and widespread job combining.

This form of labor behavior was inherent in the Soviet period. But then it was severely restricted by the state and was less relevant for the Soviet middle class, which had social guarantees from the state. After the Soviet Union collapse and the transition to market economy secondary employment (job combining) became rather popular [12]. 
There are 3 forms of secondary employment of "Soviet specialists":

1) development of new, in-demand activities in addition to the main job;

2) increase in the volume of work at the workplace;

3) self-employment.

The first form is used by "specialists", who managed to find a job "on the side": they are engineers, making money on the side, repairing household appliances, scientists guarding parking lots, military officers being carriers, etc. "Often the main work, which is mainly a place to store a work book, assumes a secondary nature by a number of indicators (for example, in terms of profitability, cost, time, value), hence, secondary employment essentially becomes the main" [13].

The second form of job combining is popular among people, trying to maintain an acceptable standard of living based on the increase of labor amount at their work place. For example, teachers take more "hours" or doctors work in several shifts.

Self-employment is typical for people who, not finding other opportunities to earn money, turn their hobby into economic activity. So, a female engineer of defense companies sews and knits in her spare time. She sells the results of her work and thus provides a subsistence minimum for the family. Often people catch fish, gather mushrooms for sale, etc.

Gardening in the first half of 1990s was the brightest example of the selfemployment strategy. Almost one third of the Russian cities inhabitants, owning a country property, tried to make up the lack of a family budget by saving on fruits and vegetables that can be grown in kitchen gardens. Instead of increasing professional activity people become involved in the production of agricultural products.

"Soviet specialists" use free time to get additional income. There are many variants of using free time, and they can not be systematized.

Institutional changes did not encourage "Soviet specialists" to replace paradigm quickly and lead to the employment strategy rationalization and the economic behavior change. This is related to social psychology, which is much more inactive than economic transformation. If the new economic was established by means of the adoption of the legislative act, ten years later most respondents still stuck to idealistic employment strategies.

\section{References}

1. Serova L.M., Stepus' I.S. Aktual'nye problemy podgotovki i trudoustroistva kadrov inzhenernotekhnicheskogo profilya v Rossiiskoi Federatsii [Critical Problems of Training and Employment of Engineer-Technical Personnel in the Russian Federation]. Rektor vuza [Rector of the University], 2014, no. 3, pp. 23-32. 
2. Toreev V.B. Monitoring sotsial'no-ekonomicheskikh izmenenii v malom biznese [Monitoring of SocioEconomic Changes in Small Business]. Narodonaselenie [Population], 2010, no. 1.

3. Toreev V.B. Rynok truda i strategii poiska raboty [Labor Market and Work Search Strategies]. Narodonaselenie [Population], 2013, no. 3.

4. Gorshkov M.K., Petukhov V.V. Molodezh' novoi Rossii: obraz zhizni i tsennostnye prioritety [The Youth of New Russia: Lifestyle and Value Priorities]. Informatsionno-analiticheskii byulleten' [InformationAnalytical Bulletin], 2007, no. 4, p. 95.

5. Trudovye strategii rossiyan (tipologiya rabotnikov po trudovym strategiyam) [Employment Strategies of the Russians (Typology of Workers by Employment Strategies)]. Fond obshchestvennoe mnenie. 2009 [Public Opinion Fund. 2009], no. 40.

6. Skrebkov D.O., Shevchuk A.V. Frilansery v informatsionnoi ekonomike: kak rossiyane osvaivayut novye formy organizatsii truda i zanyatosti [Freelancers in the Information Economy: How Russians Use New Forms of Labor and Employment Organization]. Available at: http://do.gendocs.ru/docs/index-16906. html.

7. Elkina O.S. Strategii ekonomicheskogo povedeniya rabotnikov na rynke truda [Strategies of Economic Behavior of Workers on the Labor Market]. Moscow: Informznanie, 2006, p. 468.

8. Tomilov V.V., Semerkova L.N. Marketing rabochei sily [Marketing of Workforce]. Available at: http:// www.marketing.spb.ru/read/m6/index.htm.

9. Ekonomicheskie sub"ekty postsovetskoi Rossii: kollektivnaya monografiya [Economic Actors in Post-Soviet Russia: Collective Monograph]. Under editorship of Doctor of Economics, Professor R.M. Nureev. Moscow: MONF, 2001, p. 246.

10. Gladarev B. Trudovye strategii "sovetskikh spetsialistov" v kontse 1990-x godov: problema ukorenennosti ekonomicheskogo povedeniya [Employment Strategy of "Soviet Specialists" in the Late 1990s: Problem of Embeddedness of Economic Behavior]. Voprosy ekonomiki [Economical Issues], 2004, no. 12.

11. Ledeneva A. Neformal'naya sfera i blat: grazhdanskoe obshchestvo ili (post) sovetskaya korporativnost'? [Informal Sector and Profitable Connections: Civil Society or (Post) Soviet Corporatism?]. Pro et Contra [Pro et Contra], 1997, vol. 2, no. 4, pp. 113-124.

12. Klopov E. Vtorichnaya zanyatost' kak forma sotsial'no-trudovoi mobil'nosti [Secondary Employment as a Form of Social and Labor Mobility], Sotsiologicheskie issledovaniya [Sociological Studies], 1997, no. 4.

13. Varshavskaya E., Donova I. Vtorichnaya zanyatost' naseleniya [Secondary Employment of the Population]. Zanyatost' i povedenie domokhozyaistv: adaptatsiya $k$ usloviyam perekhoda $k$ rynochnoi ekonomike $v$ Rossii [Employment and Household Behavior: Adaptation to the Conditions of Transition to Market Economy in Russia]. Under editorship of V. Kabalina i S. Klark. Moscow: ROSSPEN, 1999, p. 115.

\section{Cited works}

1. Serova L.M., Stepus' I.S. Critical Problems of Training and Employment of Engineer-Technical Personnel in the Russian Federation. Rector of the University, 2014, no. 3, pp. 23-32.

2. Toreev V.B. Monitoring of Socio-Economic Changes in Small Business. Population, 2010, no. 1.

3. Toreev V.B. Labor Market and Work Search Strategies. Population, 2013, no. 3.

4. Gorshkov M.K., Petukhov V.V. The Youth of New Russia: Lifestyle and Value Priorities. InformationAnalytical Bulletin, 2007, no. 4, p. 95. 
5. Employment Strategies of the Russians (Typology of Workers by Employment Strategies). Public Opinion Fund. 2009, no. 40.

6. Skrebkov D.O., Shevchuk A.V. Freelancers in the Information Economy: How Russians Use New Forms of Labor and Employment Organization. Available at: http://do.gendocs.ru/docs/index-16906.html.

7. Elkina O.S. Strategies of Economic Behavior of Workers on the Labor Market. Moscow: Informznanie, 2006, p. 468.

8. Tomilov V.V., Semerkova L.N. Marketing of Workforce. Available at: http://www.marketing.spb.ru/read/ m6/index.htm.

9. Economic Actors in Post-Soviet Russia: Collective Monograph. Under editorship of Doctor of Economics, Professor R.M. Nureev. Moscow: MONF, 2001, p. 246.

10. Gladarev B. Employment Strategy of "Soviet Specialists" in the Late 1990s: Problem of Embeddedness of Economic Behavior. Economical Issues, 2004, no. 12.

11. Ledeneva A. Informal Sector and Profitable Connections: Civil Society or (Post) Soviet Corporatism? Pro et Contra, 1997, vol. 2, no. 4, pp. 113-124.

12. Klopov E. Secondary Employment as a Form of Social and Labor Mobility, Sociological Studies, 1997, no. 4.

13. Varshavskaya E., Donova I. Secondary Employment of the Population. Employment and Household Behavior: Adaptation to the Conditions of Transition to Market Economy in Russia. Under editorship of V. Kabalina i S. Klark. Moscow: ROSSPEN, 1999, p. 115. 